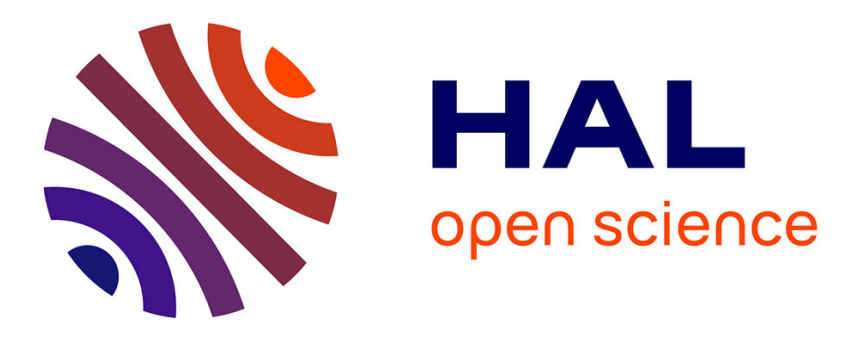

\title{
Assessing the phenotypic and genotypic diversity of Sclerotinia sclerotiorum in France
}

Christel Leyronas, Magali Duffaud, Claire Troulet, François Villeneuve, Marc Bardin, Philippe C. Nicot

\section{- To cite this version:}

Christel Leyronas, Magali Duffaud, Claire Troulet, François Villeneuve, Marc Bardin, et al.. Assessing the phenotypic and genotypic diversity of Sclerotinia sclerotiorum in France. 10. Conférence de la Société française de phytopathologie - 12. European foundation for plant pathology conference, Societe Francaise de Phytopathologie (SFP). FRA.; Université du Littoral Côte d'Opale (ULCO). FRA., May 2017, Malo-les-Bains, France. hal-01603316

\section{HAL Id: hal-01603316 https://hal.science/hal-01603316}

Submitted on 2 Jun 2020

HAL is a multi-disciplinary open access archive for the deposit and dissemination of scientific research documents, whether they are published or not. The documents may come from teaching and research institutions in France or abroad, or from public or private research centers.
L'archive ouverte pluridisciplinaire HAL, est destinée au dépôt et à la diffusion de documents scientifiques de niveau recherche, publiés ou non, émanant des établissements d'enseignement et de recherche français ou étrangers, des laboratoires publics ou privés.

\section{다(1)(2)}

Distributed under a Creative Commons Attribution - ShareAlikel 4.0 International 
10. Conférence de la Société française de phytopathologie, 12. European foundation for plant pathology conference, Malo-les-Bains, FRA (2017/05/29 - 2017/06/02).

Assessing the phenotypic and genotypic diversity of Sclerotinia sclerotiorum in France

$\underline{\text { Christel Leyronas }}^{1}$, Magali Duffaud ${ }^{1}$, Claire Troulet ${ }^{1}$, François Villeneuve ${ }^{2}$, Marc Bardin $^{1}$ and Philippe Nicot ${ }^{1}$.

${ }^{1}$ Pathologie Végétale, INRA, 84140, Montfavet, France

${ }^{2}$ Ctifl, Centre de Lanxade, 24130, Prigonrieux, France

Session "Space-time and multi-scales approaches: diagnostic, epidemiology and ecology in the field."

Sclerotinia sclerotiorum is a highly polyphagous ascomycete that can attack more than 400 plant species among which vegetables and arable crops. In order to improve the efficiency of plant protection against white mould, knowledge on the $S$. sclerotiorum populations has to be acquired. In the framework of national project "Scleroleg", S. sclerotiorum isolates were collected on symptomatic plants in several French regions. Their genetic and phenotypic diversity was assessed.

The aggressiveness of 103 isolates collected from bean, canola, carrot, lettuce, melon and witloof chicory was compared on melon, tomato and lettuce in controlled conditions. All isolates were able to cause symptoms on detached leaves of the three plant species. The relative level of aggressiveness of an isolate, compared to the others, tended to be similar regardless of the plant species on which it was assessed. On average, the isolates collected from lettuce were slightly more aggressive than the others on all three host plants tested. For the rest of the isolates, there was no link between host of origin and aggressiveness, suggesting that there is no marked host specialization of the fungus. These data were partly supported by the results of genetic characterization of 200 S. sclerotiorum isolates with 16 microsatellites markers. While there was no significant geographic differentiation among isolates (some haplotypes were shared by isolates collected on different species and separated by up to $600 \mathrm{~km}$ ), the lettuce isolates showed strong and significant genetic differentiation with all others.

The reasons for these differences remain to be elucidated. However, our study clearly suggests that sclerotia of $S$. sclerotiorum generated on one host crop will likely be capable of providing inoculum for the next susceptible crop grown in the same plot and possibly for crops in neighbouring fields, via the production of airborne ascospores.

Keywords: white mould, epidemiology, aggressiveness, genetic differentiation 